\title{
Staff and Students' Perception of Students' Participation in University Governance in Ekiti and Ondo States, Nigeria
}

\author{
Dr (Mrs) Akomolafe, C.O. And Mrs. Ibijola, E.Y. \\ Department of Educational Foundations and \\ Management, Ekiti State University, Ado-Ekiti, Nigeria. \\ Doi:10.5296/ijld.v4i2.5706 URL: http://dx.doi.org/10.5296/ijld.v4i2.5706
}

\begin{abstract}
This study investigated staff and students' perception of students' participation in university governance and organizational effectiveness in Ekiti and Ondo States, Nigeria. A descriptive research of survey design was employed. Data were collected with an instrument titled "Questionnaire on Students' Participation in University Governance" (SPUG)". 200 staff and 520 students were sampled using stratified and simple random sampling techniques. The research hypotheses raised were tested using the t-test statistics. The results were held significant at 0.05 levels. Simple percentage was employed to answer the research questions.

The findings revealed no significant difference between staff and students' perception of the level of students' participation in university governance and the level of organizational effectiveness in the system, as a moderate level of students' participation in university governance and a moderate level of organizational effectiveness was revealed. Conclusively, participation of students in university governance is perceived as worthwhile to enhance administrative effectiveness. In view of the findings of this study, it is recommended that students be represented on all university statutory committees. An increase in the number of students' representatives on university committees is also recommended.
\end{abstract}

Introduction

Over the decades, many African countries and most especially Nigeria, has been clamoring for the sustainability of democracy, which is the government of the people by the people and for the people. Literature has revealed that for democracy to survive, not only the appropriate political parties need be put in place. Bergan (2005) opined that higher education has been recognized as key to delivering the knowledge requirements for political development while Akomolafe and Ibijola, (2012) submitted that students' participation in university governance allows for development of leadership. Lambert (2012) posited that the campus is now the most veritable training ground for future politician and leaders. He further stressed that students who participate in unionism may not necessary be studying political science or similar courses, but they are people who are inclined to politics. Observation have also shown that, most politicians, have at one time or the other played very active role in campus politics during their school days. There have been instances also where formal student leaders later lead political or informal organizations, after graduation.

Consequently, if extra-curricular students development and students participation in university governance could serve as a training ground to instill and support democratic values and practices, then students should be allowed their rightful place in university governance. However it is on records that the historical struggle of the Nigerian students for a democratic culture and tradition in the Nigerian society predates any of the existing political parties to the struggle for power. On this premise, one would agree that higher education has a very strong 
role to play in the sustainability of democracy of any nation. While recognizing the role and importance of youths in development, the former military governor of Lagos State, Group Captain Mudasiru Lawal on April 30, 1985 while launching the Lagos chapter of the International Youth Year noted the need for full participation of the youths in all activities that would make Nigeria great, Adesanoye (1989). According to him, the youths must be fully involved in the drive towards social, political and economic development of the country. He further declared that, the cruel issue of our time is remolding their potential leadership to meet the demand and aspirations of Nigerians for a prosperous, united and dynamic nation.

The works of Weber, Sterwart, Baldbridge, Richman and Farmer cited in Aluko et al (1997) conceptualized universities as communities, collegial, political and complex . Corroborating this view, Rotem and Glasman cited in Aluko et al (1997) asserted that the university is not one community but several, while Ede (2000) described universities as international community's engaged in the daily business of search for knowledge and truth. Bergan (2005) submitted that, as members of the academic community, students share a responsibility of their education and for the institution which provides the framework for this education. It is therefore worth noting that the idea of taking students as clients, receivers or buyers of a final product in the university system contradict the idea of seeing students as members of the academic community.

The review of related literature revealed that throughout the world, universities are managed by committee system, which plays a very important role in the decision making process, as it allows for democratization of the decision making process. Akomolafe (2002) submitted that a democratic leader should believes in consultation and joint decision-making as it is one of the principles of decision making process. However, it is obvious that, despite the numeric strength of the students, they still hold minority member seats on very few university committees, thereby making their contributions at such committee meetings very insignificant in decision making, and this seems to be a major factor of the instability in the Nigerian university system. In a research work conducted by Akomolafe and Ibijola (2012), they submitted that when students are involved in university governance, it has a positive correlation with organizational effectiveness.

Kanperin (2004) while stressing the importance of student's participation in university governance viewed students' participation in the university governance as when students feel responsible for their learning. Participation and leadership in formal settings such as student government on campus and voluntary associations on or off campus are among the typical indicators of active citizenship, Saha (2000). Akomolafe and Ibijola (2012) revealed that the rationale for students' participation in university governance among others includes; higher degree of level of commitment on the part of the students, easy attainment of set goals or objectives, efficient policy formulation and implementation, uninterrupted flow of academic programmes, leadership training and development, stable economic gain and reduction in crime or anti-social behavior on the part of the students. Observations have shown that students have so much regards for their union executives even more than for the university authorities probably because they believe in the course of their leaders. Therefore, the student union government makes the process of democratic representative and participation in the Faculty and the University decision making bodies easier. By implication, formal student representation in university governance have been serving as a training ground for leadership in civil society, as the skills and competencies acquired in the university context could immediately be transferred to organized civil society.

\section{Purpose of the study}

The staff and students' perception of the level of students' participation in university governance are investigated with the purpose of ascertaining to what level students are 
involved in leadership training through their involvement in university governance. Staff and students' perception of the level of organizational effectiveness in university governance was also investigated in order to correlate the perceived level of students' participation with that of organizational effectiveness.

\section{Statement of the problem}

Research have shown that students' participation in university governance allows for leadership training, while some authors and researchers opined that higher education has been recognized as key to delivering the knowledge requirements for political development. Many authors and Researchers have affirmed to the fact that the university system is a community and that the students are the main-stakeholder in education. It has however become a thing of concern to know that despite the numeric strength of the students in Nigerian universities, they still hold minority member seats on very few university committees.

Based on the aforementioned problems, the study therefore investigated the perception of staff and students on the level of students' participation in university governance, and the organizational effectiveness in the system. To guide the study, the following general questions were raised;

i. What is the staff perception of students' participation in university governance?

ii. What is the students' perception of their participation in university governance?

iii. What is the staff perception of the level of organizational effectiveness in university governance?

iv. What is the students' perception of the level of organizational effectiveness in university governance?

\section{Research Hypotheses}

In order to answer the research questions, the following Null hypotheses were formulated:

i. There is no significant difference between staff and students' perception of students' participation in university governance.

ii. There is no significant difference between staff and students' perception of level of organizational effectiveness in university governance.

\section{Methodology}

The study employed a descriptive research of survey type. Survey method was used because it provides methodological design at investigating the human behavior, opinion and perception when the population is large and there is need to introduce elements of sampling into a study. The population for this study consisted of all staff and students of the Ekiti State University Ado-Ekiti, Ekiti State and Adekunle Ajasin University, Akungba-Akoko ,ondo state.

The sample for the study was made up of 720 subjects, consisting of 60 students' union executive members, 200 students, 50 top university administrators, and 50 lecturers from each of the two universities covered by this study. Stratified random and simple random sampling techniques were used to select the samples. The population was divided into strata based on the groups within the university, while simple random sampling technique was used to select the samples from each stratum.

A questionnaire titled "Students' Participation in University Governance (SPUG)" was the instrument for collecting data. The respondents were to indicate their responses for sections B in terms of: strongly agree (SA), agree (A), disagree (D), strongly disagree (SD) and indifference (I) to each of the statements in the columns provided. Section C contained a list of twenty statements in which respondents were to indicate their responses in terms of strongly 
effective (SE), effective (E), rarely effective (RE), not effective (NE), and indifference (I) to each of the statements in the columns provided. Scoring was done using the Likert rating scale. Strongly agree (5), agree (4), disagree (3), strongly disagree (2), and indifference (1) and strongly effective (5), effective (4), rarely effective (3), not effective (2), indifference (1) were used.

In order to ensure the face and content validity of the instruments, two experts in Test and Measurement examined each item of the instrument. Their observations were used as a guide in reviewing the instrument before administering them on the subjects. The reliability of the instrument was ascertained using the split-half method and the Spearman Brown prophecy formulae. The resulting co-efficient was 0.90 .

The researchers administered the instrument with the assistance of research assistants. The data obtained from the instrument were analyzed. Simple percentage was employed to answer the research questions. The research hypotheses were tested using the t-test statistics at 0.05 level of significance. The mean scores on staff and students' perception on participation in university governance and level of organizational effectiveness and their corresponding standard deviation were used to categorize the subjects into three groups representing levels of participation and organizational effectiveness respectively. The result is presented in table 1 and graphically represented in figures 1 and 2 below.

\section{Results and discussion.}

Research question 1.

1. What is the staff and students perception of students' participation in university governance?

Table 1: Staff and students' perception of level of students' participation in university governance

\begin{tabular}{|c|c|c|c|c|c|}
\hline \multirow[t]{2}{*}{ Level of perception } & \multicolumn{2}{|r|}{ Staff } & \multicolumn{2}{|c|}{ Students } & \multirow{2}{*}{ Total } \\
\hline & $\mathrm{F}$ & $\%$ & $\mathrm{~F}$ & $\%$ & \\
\hline Low: $\quad(41-57.28)$ & 23 & 11.5 & & & 106.0 \\
\hline Moderate:(57.29-79.87) & 140 & 70.0 & & & 464 \\
\hline High: (79.88-100) & 37 & 18.5 & & & 150 \\
\hline Total: & 200 & $100.0 \%$ & & & 720 \\
\hline
\end{tabular}




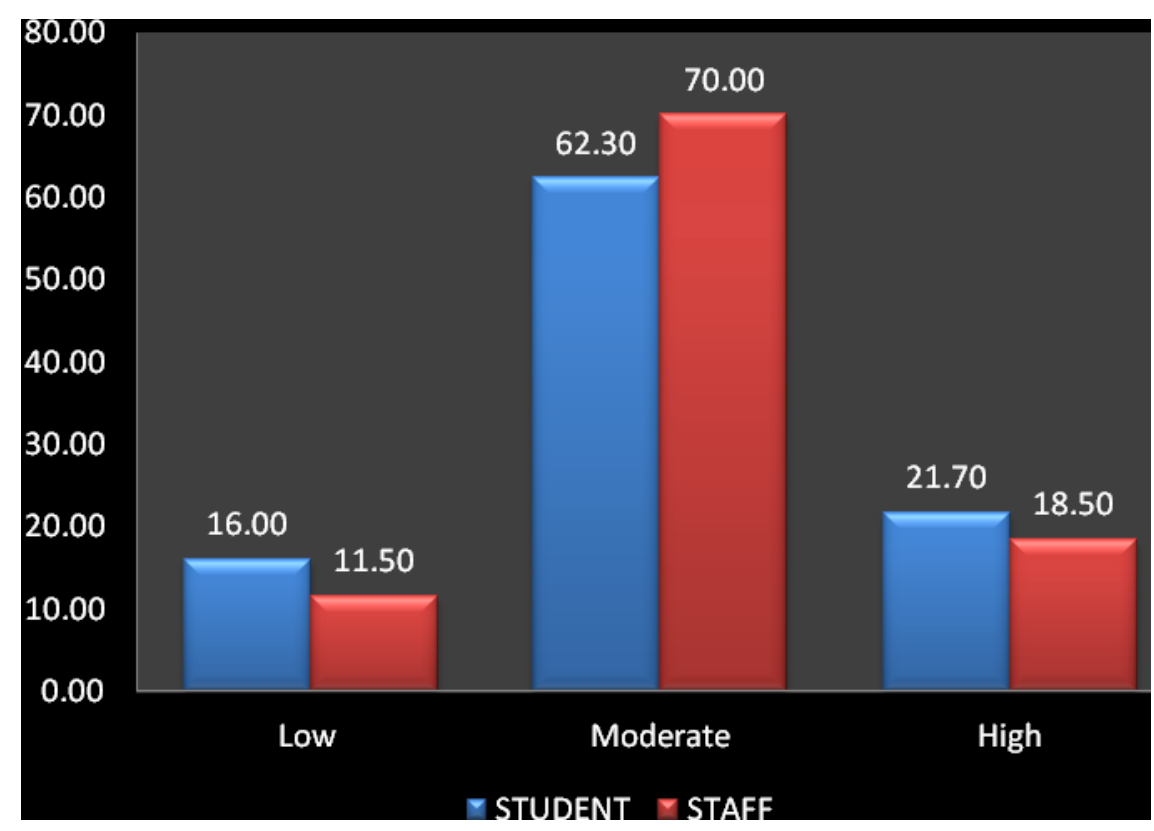

Figure 1: Graph showing level of staff and students' perception of students' participation in university governance

Table 1 and figure 1 show the staff and students' perception of students' participation in university governance. Analysis of the results show that (11.5\%) of the staff and (16.0\%) of the students perceived students' participation in university governance as low, $(70.0 \%)$ of staff and $(62.3 \%)$ of students perceived the level of students' participation as moderate, while $18.5 \%$ of staff and $2.7 \%$ of students adjudged the level of students participation in university governance as high. From the above analysis, it is obvious that the perception of both staff and students for the moderate level of participation is above $60 \%$. Hence, one may conclude that the perception of both staff and students revealed a moderate level of students' participation in university governance.

Table 2: Staff and Students' perception of level of organizational effectiveness in university governance 


\begin{tabular}{|c|c|c|c|c|}
\hline \multirow[t]{2}{*}{ Level of perception } & \multicolumn{2}{|r|}{ Staff } & \multicolumn{2}{|c|}{ Students } \\
\hline & $\mathrm{F}$ & $\%$ & $\mathrm{~F}$ & $\%$ \\
\hline Low: $\quad(33-61.15)$ & 36 & 18.0 & & \\
\hline Moderate:(61.16-83.28) & 148 & 74.0 & & \\
\hline High: (83.29-100) & 16 & 8.0 & & \\
\hline Total: & 200 & $100.0 \%$ & & \\
\hline
\end{tabular}

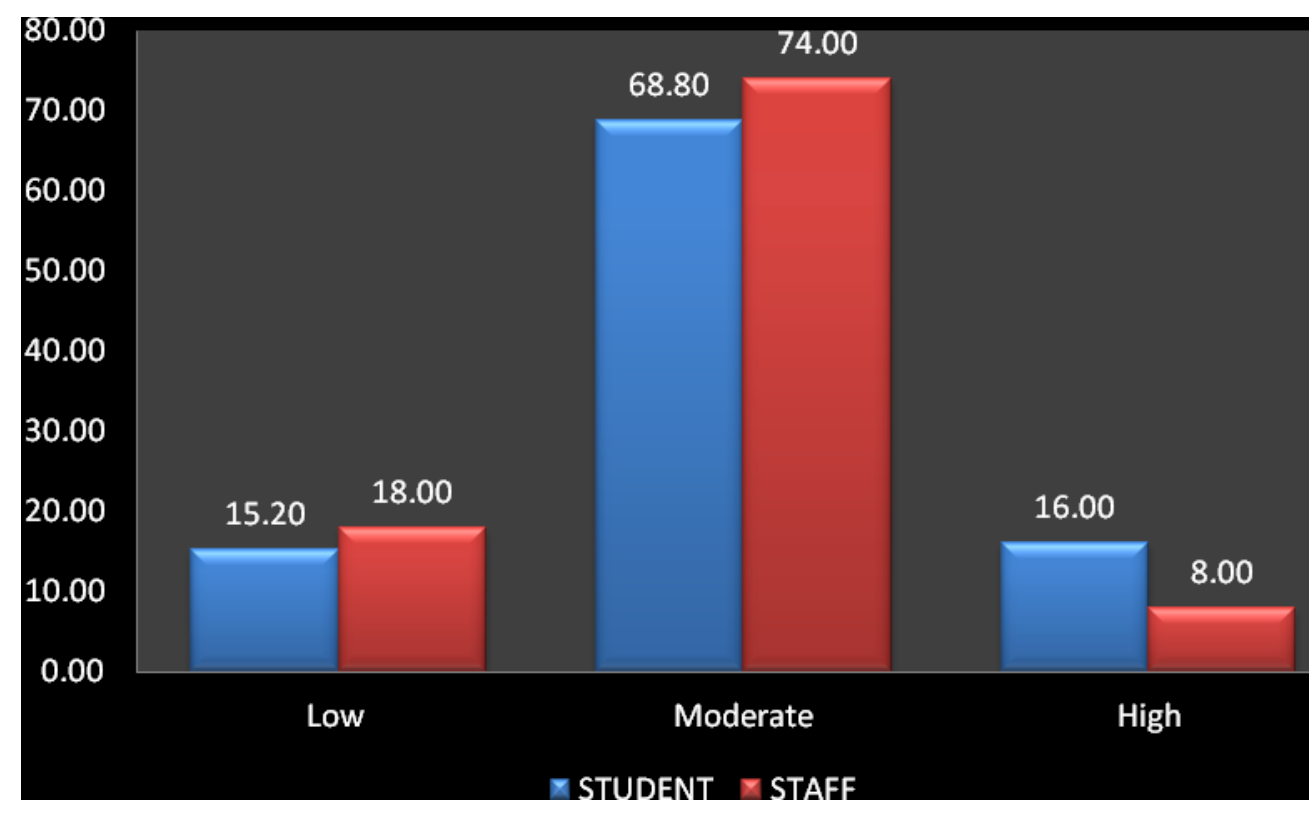

Figure 2: Graph showing the level of staff and students' perception of organisational effectiveness in university governance.

Table 2 and figure 2 revealed that (18\%) of staff respondents and (15.2\%) of student respondents perceived the level of organizational effectiveness as low. (74\%) of staff respondents perceived level of organizational effectiveness to be moderate and $(68.8 \%)$ of the student respondents perceived it as moderate $(8 \%)$ of staff and $(16 \%)$ of students respondents' adjudged the level of organizational effectiveness in university governance as high. The analysis above revealed that $(68 \%)$ and above of all the respondents perceived the level of organizational effectiveness as moderate. Based on the findings of this study therefore, one may conclude that the level of organizational effectiveness is neither high nor low, but moderate. By implication, the staff and students perceived moderate level of students' 
participation has a positive correlation with the perceived moderate level of organizational effectiveness.

\section{Hypothesis 1}

There is no significant difference between staff and students perception of level of students' participation in university governance.

Table 3: t-test analysis on staff and students' perception of students' participation in university governance.

\begin{tabular}{|c|c|c|c|c|c|c|}
\hline Group & $\mathrm{N}$ & Mean & SD & Df & t-cal & t-table \\
\hline Student & 520 & 69.63 & 11.81 & 718 & 1.165 & 1.960 \\
\hline Staff & 200 & 70.76 & 11.22 & & & \\
\hline
\end{tabular}

$\mathrm{P}>0.05$

Table 3 shows that $t$-cal value of (1.165) is less than t-table value of (1.960) at 0.05level of significance. The null hypothesis is therefore, accepted. This shows that there is no significant difference in the perception of staff and students on students' participation in university governance.

\section{Hypothesis 2}

There is no significant difference between the staff and students' perception of level of organizational effectiveness in University governance

Table 4: t-test analysis on staff and students' perception of organizational Effectiveness in university governance.

\begin{tabular}{|l|l|l|l|l|l|}
520 & 73.02 & 10.75 & 718 & 1.184 & 1.960 \\
\hline 200 & 72.01 & 8.94 & & & \\
\hline
\end{tabular}

$\mathrm{P}>0.05$

Table 4 shows that $t$-cal value of (1.184) is less than t-table value of (1.960) at 0.05 level of significance. Therefore, the null hypothesis which states that there is no significant difference between the staff and students perception of organizational effectiveness in university governance is accepted. Hence staff and students have similar perception of organizational effectiveness in the university.

\section{Discussion}

The findings of this study revealed that, the level of students' participation is moderate, as the perception of both staff and students on the variable do not differ. This confirms the opinion of Bergan (2011) who opined that students are not represented on all university committees despite their numerical strength, even though he asserted that the role of students in 


\section{Macrothink}

higher education is that of the main stakeholders. If the university is seen as a community as affirmed by Ede (2000) and Aluko (1997), then, students should be given their rightful place in university governance by ensuring that students are well represented on all university committees.

The study also revealed that, there was no significant difference between staff and students' perception of level of organizational effectiveness in university governance. The fact that the staff and students' perception revealed no significant difference is a confirmation of the moderate level of students' participation and of organizational effectiveness in university governance.

\section{Conclusion}

The effective administration of university is desirable more than ever before in this digital age as such, the university system cannot afford to ignore the role students' participation could play in the effectiveness of management. Consequently, participation of students in university governance is perceived as worthwhile to enhance administrative effectiveness. The perceived staff and students' moderate level of students' participation in university governance as revealed by this study is an indication that students do not take part in all university committees, while the perceived moderate level of organizational effectiveness established by this study signifies inefficiency in the system. This means that the perceived level of students' participation in university governance has a positive correlation with the perceived level of organizational effectiveness. The perceived moderate level of students' participation and organizational effectiveness in the university governance established by the study implies that organizational effectiveness could be increased to a high level with increase in level of students' participation in university governance.

\section{Recommendation}

In view of the findings of this study, it is recommended that students be represented on all university statutory committees. An increase in the number of students' representatives on university committees is also recommended. 


\section{References}

Adesanoye, A. P. (1989): A study of Students participation in School Management. A case study of some Secondary Schools in Ikale Local Government Area of Ondo State; An unpublished M.Ed (Educational Administration) thesis. O.A.U. Ile-Ife.

Akomolafe C. O. (2002): Principals' behaviour and staff development in Ekiti State Secondary Schools. Unpublished $\mathrm{PhD}$ Thesis.

Akomolafe, C. O. and Ibijola, E. Y. (2012): International Journal of Education Administration and Policy Studies Vol. 4(1), pp. 14-18, January 2012. Available online at http://www.academicjournals.org/IJAPS

Aluko, M., Odugbesan, O., Gbadamosi, L. (1997): Business Policy and Strategy. Remof Themes Limited (Educational Publishers), Lagos. Nigeria.

Bergan, S. (2005): Student participation in higher education governance. Retrieved from http://www.int/t/dg4/highereducation/resource/heseries_en.asp. on August 30, 2012.

Ede, S.A. (2000): Educational administration and Management, Jos, Nigeria: Ichedum Publication Nigeria, Ibadan, Nigeria Spectrum Books Ltd.

Kanperin D. (2004): The Use and Abuse of Student participants, Vol. 17, Part 5, May 2004, Retrieved from www.thepsychologist.org.uk on Feburary 20, 2013.

Lamber, V. (2012): 'Deception in Students Politics: The Nation newspaper of Thursday, April 19,2012 pg 35

Saha, L. (2000): Education and Active Citizenship: Prospects and Issues; Educational Practice and Theory, Vol. 22, no. 1, pp. 9-20. 